\title{
Consumer Payment System and the Challenge of Confidence in National Payment System of Developing Countries: A Case Study of Nigeria
}

\author{
Dr Adeyeye Adewole
}

\author{
Ondo State University of Science and Technology, Okitipupa, Ondo State, Nigeria \\ Email: dradeyeyeadewole@gmail.com
}

\section{Doi:10.5901/mjss.2015.v6n2s1p568}

\begin{abstract}
Given the emerging global financial order which makes it imperative for consumer payment systems to elicit strong consumer confidence towards sustainable national and international financial system; the paper examines confidences in consumer payment systems of developing countries with particular focus on Nigeria. Using randomly-selected samples of consumers across the Nigerian banking industry, the study examines the confidence level in Nigeria consumer payment system in terms of how the system guarantees consumer service and convenience; and how it is free of fraud and other forms of unethical practices. The study indicates that the Nigerian consumer payment system is fraught with all manners of unethical practices that have reduced confidence level. It observes that low level of consumer confidence in Nigeria's banking system have serious implication for effectiveness and support for sustainable national consumer payment system. The study concludes by identifying ways in which strong consumer confidence can be achieved in the Nigerian consumer payment system.
\end{abstract}

Keywords: Consumer; National Payment System; Confidence; Developing Country

\section{Introduction}

Consumer payment system is an essential banking responsibility. It refers to formal banking arrangements that allows for transfer of monetary value. It is an operational network governed by laws, rules and standards that link bank accounts and also provides functionality for monetary exchange using bank deposit (Summer 2012). Consumer payments system is so called because it is a system that deploys cash-substitutes and other related alternative payment mechanism. Every payment system consists of three elements. These according to (Mark, 2008) and the Committee on Payment and Settlement Systems (CPSS 2009) are: core fund transfer application mechanism; existence of infrastructure that makes it easy to access the system and the operating procedures governing access to the system. The available types of consumer payment systems include the traditional cash-payment system, cheque payment system, electronic fund transfer and the on-line banking payment system. While each of these systems has its relative strength and weaknesses, the critical lesson one has learnt over-time about types of consumer payment systems is that subsequent system is always an attempt at reducing the problems associated with previous ones.

Because of this, consumer payment systems have been able to undergo radical innovations. Hence, the history of consumer payment system is about how consumers have accepted and supported successive innovations over-time in a way that brings about system effectiveness and consumer satisfactions. From the traditional cash-payment mechanism through checks and cards up to the modern fund transfer system; the electronic payment is replacing traditional paperbased system while card payments are displacing checks. Hi-tech mechanisms such as electronic pursuits portend entirely new pattern of payment systems such as on-line payment system. With improved computer technology, electronic payments have taken the front banner. We now have credit cards, debit cards, internet banking, and etransact. There are also other payment systems to address cash transactional activities in local and international businesses. (Agene 1999, Singh 2009) identifies the characteristic features of modern consumer payment system to include: standardization of consumer payments in a way that enhances quick service and convenience; electronic approach that is compact and technology driven; fast and timely response to emerging global payment systems; enhancement of international movement of capital and resources on- time and real-time; a fraud free system devoid of unethical practices.

The importance of payment system in the financial structure of any nation cannot be over-emphasized. In developed and under-development countries, the consumer payment system has proven to be excellent conduit for executing economic choices. It has also allowed for radical changes in national economies of most nations. The payment 
system therefore according to (Tyree 2012) represents the tripod stand upon which effective operation of central banking functions such as monetary control, supervision and regulation rests.

The major challenge in consumer payment system however is about how and the extent at which consumer confidence is assured in each and all of the system. Consumer confidence is about convictions and guarantee that consumer payment services will achieve the expectations of consumers. Essentially, effective and efficient payments that engender confidence in consumer have become invaluable infrastructure in modern business. This is simply because all businesses and financial transactions involve one payment or the other. When a transaction is not paid for in cash (in the forms of notes and coins), it is paid for through any of the arrays of fund transfer mechanism that are allowed in national consumer payments system.

In global financial scene, there is a greater concern for confidence in consumer payment systems (Asolo A. 2001). Closer attention and scrutiny are being exerted on how present and future consumer payment systems should operate within the context of certain minimum standards that can promote and engender confidence in banking services. Therefore, the need for appropriate confidence infrastructure has become indispensable for meaningful and sustainable consumer payment system. Infrastructure in consumer payment system is expected to build strong confidence in order to enhance success of the system.

Confidence issues that have implications for consumer payment systems include: system that allows the operational methods within a legal framework to instill confidence. It is also about how payment systems place depositors or consumers interests above pecuniary interests of operators. There is also the issue of how payment systems allow for meeting trade related transactional agreements. Other specific confidence issues in consumer payment systems include existence or absence of fraud and other fraudulent practices; payment system credibility; appropriate consumer protection; system/platform effectiveness, issue of fair and equitable conflict resolution; and the problem of real time and on time identity verification system (Agene 1999, Ayo C \& Babajide.D 2006)

While efforts are being intensified especially in developed countries to address the issue of confidence in consumer payment system against the backdrop of emerging global ethical financial order (GEFO), there has been greater demand for transparency, security, honesty and fairness in financial payment system with implications and serious concern on confidence in consumer payment systems particularly in the way it has acted as incentives to sustainable financial system. Concerns on consumer confidence in payments system in developing countries for instance have become inevitable because of the effects on individual national economy. There is also the implication for emerging international banking inter-operability and its attendant consequences on international co-ordination and co-operation, particularly with regard to minimum acceptable standards. If emergence of international financial intermediation has made it compulsory to establish internationally comparable framework based on increased across-the-border financial activities according to (Asolo Adeyeye 2005), there is need to embark on periodic confidence analysis of consumer payment system in developing countries for proper integration into the mainstream international global financial framework.

Financial institutions in developing countries were stagnated in their payment systems. The economy of most developing countries is predominantly cash economy. The situation is not unconnected with the political and socioeconomic evolution of developing countries. Developing countries are new entrants into modern socio-economic, political and financial configuration. Despite the fact that the banking institution experienced phenomenal growth "between" 19861992 in Nigeria for instance, the payment system did not grow. Some of the reasons accounted for this appalling situation include national economic down-turn, slow and rowdy clearing process, absence of customer orientation and the menace of fraud in the financial sector. (Ikpefa 2007, Sanni 2009)

From 1999 and beyond however when most developing countries started taking on new political and economic impetus with focus on deregulation, privatization, commercialization and the opening of their economic landscape for mass local and global business competition. (Asolo 2001), banking institutions in most of the countries were challenged to brace-up for competition-driven innovations in their consumer payment systems. The resultant effect is systematic but slow innovations in consumer payment system that covers cash, cheque, electronic fund transfer, credit card and on-line banking.

In Nigeria, electronic payment system is an emerging phenomenon. Other innovations that have occurred in Nigeria's banking consumer payment systems could be said to have started in less than two decades. Nigeria has elaborate consumer payments system under the auspices of National payment systems. The objectives of Nigerian national payment system according to the Central Bank of Nigeria (CBN) include among others, to promote efficiency, enhance real time gross settlement system, promote efficiency, safety, transparency, migration to cash-less method of payment, integration of national payment system with international financial infrastructure and instilling public acceptance and confidence.

Like other developing countries of the world, there are concerns on consumer confidence in Nigerian consumer 
payment systems. The issue of consumer confidence is important because of the need for Central Banks in developing Countries to achieve payment system stability and improved monitoring. Consumer confidence is also essential for effective payment system in order to achieve the objective of total quality financial delivery. Another critical reason why consumer confidence has become imperative is the exigencies of internationalization of financial payment system in which national payments system has become part and integral of entire global financial configuration. For this reason, each national payment system must work to guarantee certain measures of consumer confidence. This is why policy frameworks and efforts by the Central Bank of developed countries periodically insists that consumer payments systems should fulfill mandates that include improving confidence among consumers. This is necessary in view of existence of activities that may likely inhibit consumer confidences.

In Nigeria for instances, there is infrastructure problem in banks and there are credibility deficits among bank officials. We have high incidences of fraudulent activities in Nigerian Payment System. Apart from legitimate concerns for fairness, probity, honesty, transparency and accountability in consumer payment systems there are other basic issues such as avoidance of systemic fraud, applicable dispute resolution schemes, balanced risk transference, adequate protection of user right, avoidance of consumer rip off, effective system regulatory frameworks etc. which have become hallmarks of effective payment system. It is somewhat pathetic that despite efforts to minimize fraud in the emerging online payment systems; the system faces various threats in Nigeria with the Fraud Center in the United States alerting against international consumer payment transactions from Nigeria. (Owolabi 2009, Adeyemo 2012). The Central Bank of Nigeria (CBN) as far back as 2012 raised alarm on 162,000 cases of dud cheques valued at N166 billion. In 2013, the CBN through policy guidelines warned that cashless policy is being threatened. Subsequently, the Central Bank directed commercial banks to strengthen information management in order to enhance confidence in the system.

With various unsubstantiated reports of sharp practices in Nigerian banking activities and the implications for consumer confidence, there is a need to determine a level of consumer confidence in Nigerian payment systems. This study examines confidence level of consumers in Nigeria payment system. It examines the responses of Nigerian consumers to the issue of sharp and other related practices in Nigeria's payment system. The study attempts an answer to the question of whether an average Nigeria consumer has confidence in national payment system. This is necessary because certain level of consumer confidence is indispensable for sustainable consumer payment system. It is also important as a basis for comparative analysis of national payment system (NPS) in view of increasing international financial intermediation mechanism between and across countries.

This literature review attempt to establishes the context in which concerns on consumer confidence has become a major issues as a peculiar to effective national consumer payment systems.

Essentially, the specific and clear objectives of the study includes among other to determine level of confidence in Nigerian consumer payment system; isolate the consumer confidence level of Nigerian National Consumer Payment Systems against the against backdrops of international comparative analysis of national payment systems in general. The study is significant because of the increasing importance of consumer confidence towards effective national payment system. The study is expected to assist in consumer confidence policy formulation and designs towards effective consumer payment system.

\section{Methodology}

Most of the data used for the study were collected through the use of questionnaires. The questionnaire method is adopted because it is the most appropriate research instrument. The questionnaire method pre supposedly is a collection of questions to which the interviewee is expected to respond (Shokan, 1999). It is the best method for stimulating accurate response and data which is meaningful for analysis. Although, 1200 questionnaires were sent out on the basis of 48 questionnaires per each of 21 Nigerian consolidated commercial banks. At the end, 1168 were returned fully completed. The questionnaires were addressed to customers of each of the sampled banks. Customers are to explain the level of their confidence in Nigerian consumer payment systems as they transact business with banks. The choice of bank customers is informed by three basic reasons. First, recent research indicates that customers are at the receiving end of all manners of customers' payment systems in banking activities (Adeoti \& Osotimehin, 2011). Secondly, bank customers represent the critical factor in confidence analysis of bank practices particularly consumer payment mechanism. Finally, the choice of consumers is informed by the works of (Magnusson \& Carper 1968, Menon.B \& Jagathy R 2012) and other authors which emphasize the role of consumer as holding the ace to effective assessment in a given banking business transactional relationship.

The questionnaire involves responses to (4) blocks of questions. Each block contains a number of questions. Block (1) contains demographic questions about respondent. Questions on age, level of education and business specializations 
were asked. Block (2) involves information on respondents' background knowledge of consumer payment system in Nigeria. It asks questions about respondent's knowledge of the characteristic features of consumer payment. Block (3) asks questions about practices that impinge on consumer confidence in Nigerian payment system and encounter with fraud or unethical practices; consumer protection, conflict resolution etc. It also asks respondents to rate consumer payment system in Nigeria. Block (4) elicits information about what accounts for confidence level of consumers and how it can be improved upon. Close-ended questions were asked in order to maintain standard.

\section{Analysis of Results}

The first block of questions elicits information on the characteristics of customer in Nigerian banking payment systems. The demographic survey indicates that the average customer in Nigerian payment system is about 20 years old. $41 \%$ of customers in Nigerian banking payment system fall within the age bracket 40years and above while 400 respondents or $35 \%$ are between 20 and 39 years old. About 33\% of customers of Nigerian payment system possess university degree or professional certificate while 461 respondents or $40 \%$ have only secondary education. Only 16 respondents or $1 \%$ had no educational qualification. 479 respondents are gainfully employed while $34.5 \%$ or 403 respondents are engaged in one form of self employment or the other. $24.4 \%$ or 286 of the respondents are unemployed.

The second block explores respondent's knowledge of Nigeria consumer payment system. It is interesting to note that 1,168 or $100 \%$ respondents subscribe to cash payment system in Nigeria. This is followed by cheque system, which is 762 or $65 \%$. The survey also indicates that electronic fund transfer (EFT) is an emerging phenomenon in Nigeria with only $11 \%$ or 126 respondents. Credit Card/ATM system and on-line banking is also an emerging system in Nigeria with combined vote of 910 respondents or $77.9 \%$. As a corollary to this, 1,158 or $99.1 \%$ agree that cash payment system is more prevalent. This is followed by cheque system which is 705 or $60.3 \%$, electronic fund transfer 340 or $29.1 \%$; credit card 839 or $71.8 \%$ and on-line payment system $02(0.17 \%)$. About $55.3 \%$ of respondents agree that the existing infrastructure for cash payment system is very effective, 461 or $39.4 \%$ insists that it is in effective; while 902 or $77.2 \%$ that infrastructures for electronic fund transfer (EFT) are ineffective.

The third block focuses respondents' confidence in payment system and practices that impinge on consumer confidence in Nigerian payment system, such as encounter with fraud and other forms of unethical practices. The study indicates that 726 respondents or $62 \%$ does not have confidence in Nigerian consumer payment system. It also indicates that 1,006 or $86 \%$ identified lack of integrity as a factor that impinges on the confidence level of consumer in Nigeria payment system. Other factors identified as impediments to consumer confidence and the percentage (\%) number of respondents are as follows: poor infrastructure 1,068 or $91.4 \%$, prevalence of fraud 1,102 or $94.3 \%$, poor consumer protection 902 or $77.2 \%$, exposure of consumer to risks 1,030 or $88.1 \%$ and unfair cost of financial transaction 1,059 or $90.9 \%$.

In rating the confidence level of respondents on each of the available payment systems in Nigeria, the study indicates that 969 respondents or $82.9 \%$ rated high; confidences in cash system of payment; $52 \%$ or 612 rated cheques high; while $74.4 \%$ or 860 and $32.7 \%$ or 382 respondents rated online banking and Credit Card/ATM low.

The fourth block indicates that 1,024 respondents or $87.6 \%$ asserts that they have had direct encounter or issues that weaken confidence in Nigerian payment system. Only $12.3 \%$ or 144 agree that they do not have any encounter with issues that affect their confidence in Nigerian payment system. 796 respondents or $68 \%$ rate Nigerian payment systems poor. Only $26 \%$ or $2.2 \%$ rate the payment system better. 864 or $73.9 \%$ respondents identified platform related infrastructure as the major determinant of confidence level. 1,162 or $99.4 \%$ asserts that fraud and credibility issues, while 1,138 or $97.4 \%$ insists that safety and security are factors to contend with as far as confidence level in Nigeria consumer payment system is concerned.

1,096 or $93.8 \%$ agreed that safety and security issues should be improved in Nigerian consumer payment systems. 1,113 or $95.2 \%$ supported the need to ensure credibility and fraud reduction while 846 or $72.4 \%$ respondents advocated for effective payment system infrastructure and platform in order to achieve sustainable consumer confidence in payment system.

\section{Conclusion}

The study has been able to unearth some critical issues in Nigeria consumer payment system. Apart from gauging the confidence level of consumers, it has helped identify major problems that are responsible for low level of consumer confidence. It underscores the needs to improve payment system infrastructure in order to have effective payment system. This study is a confirmation of studies and reports on the imperative of sustainable confidence inclined 
infrastructural backbone for effective payment system improvement.

It is interesting to note that despite emerging popularity of ICT deployment through EFT and RTGS in consumer payment system, very few Nigerians are averse to electronic modes of payments. Further research work may needed to be conducted on why this is pitiably so. The study indicates that most Nigerians prefer cash system to other forms of payments. This is due to so many reasons. There is lack of confidence in the payment system due to credibility deficit. Secondly, the payment system infrastructure is such that it does not seem to guarantee adequate service and prompt customer satisfaction. Infrastructure breakdown is a common occurrence that distorts effective system at will. Hence, customers prefer to transact business using cash instead of being subjected to unnecessary hassles. Most bank consumers in Nigeria have had one encounter or the other with issues that reduce or threaten confidence in Nigeria payment system. Some of their encounter includes infrastructural failure, fraud in the system, security of consumer identity etc. Almost all the respondents agreed that there is need for overhaul of Nigeria payment system in order to engender consumer confidence. They identified effective platform and infrastructure, fraud reduction and improved safety and security as areas that should be improved upon.

While the study is hampered by its size, the research on Nigerian consumer payment system has thrown up the challenge of embarking on further separate studies in each of the payment systems. The results are particularly relevant on confidence analysis of consumer payment system against the backdrop of national geo-political perspectives. Apart from the fact that the study aggregates the consumer payment systems in Nigeria in anticipation of the improved infrastructure for the country, the result constitutes essential input from developing countries into the study of emerging global financial systems given the challenge of establishing an internationally comparable framework for sustainable global financial ethical order.
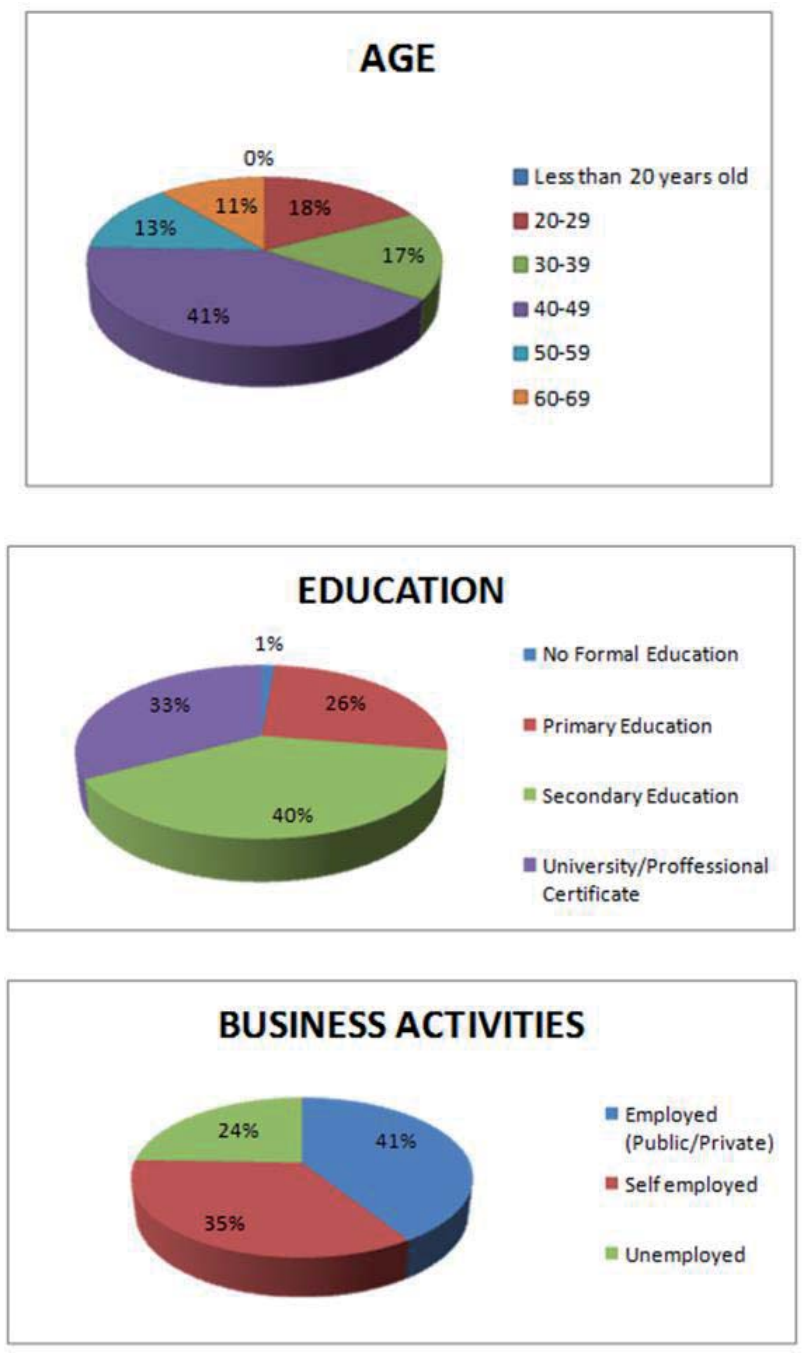

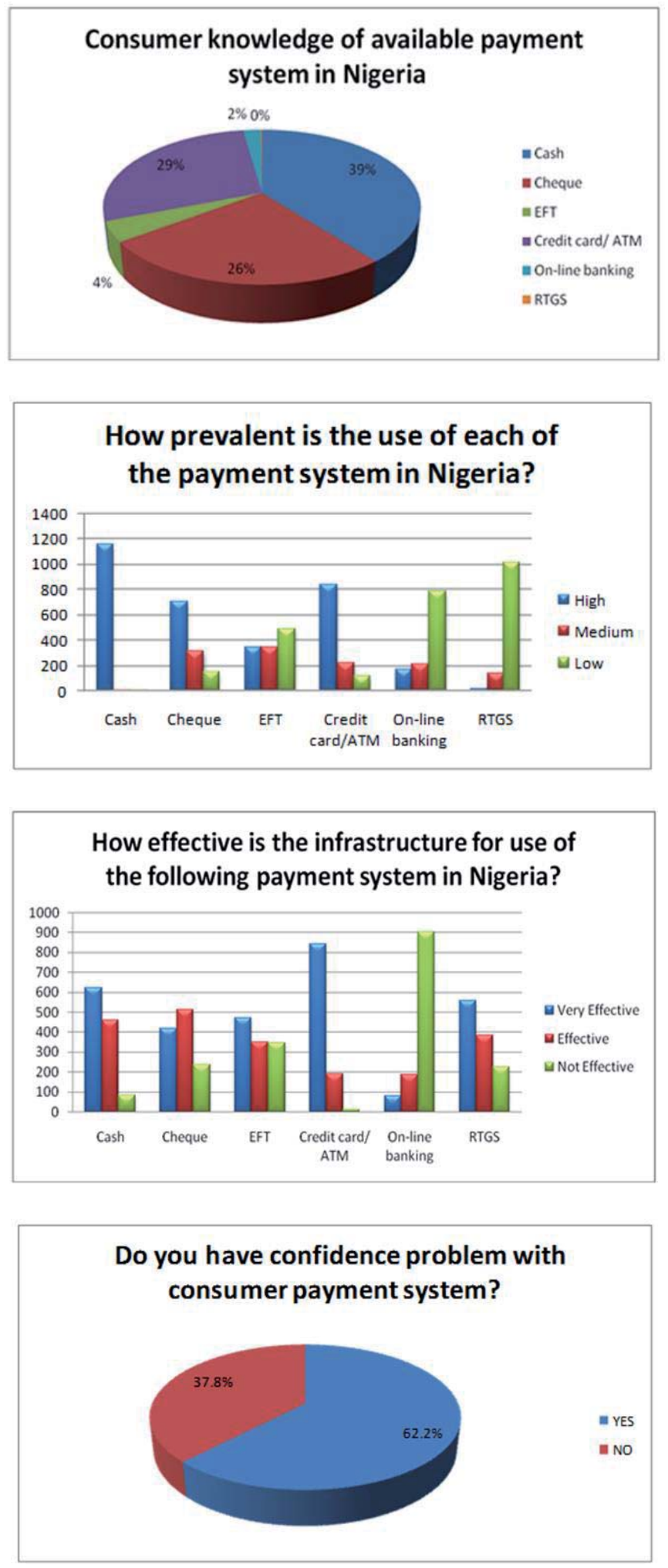

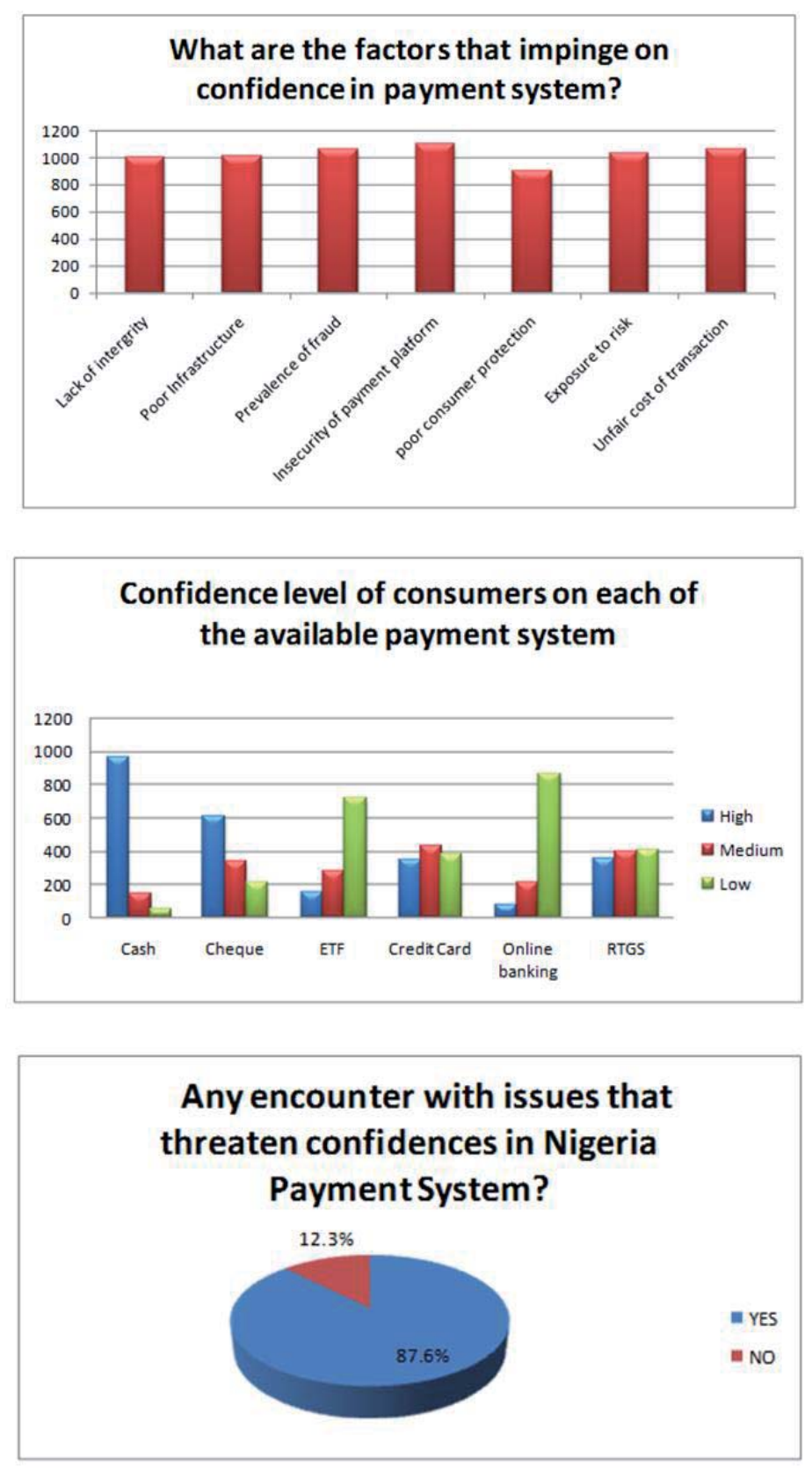

\section{Rate consumer confidence in Nigeria Payment System}

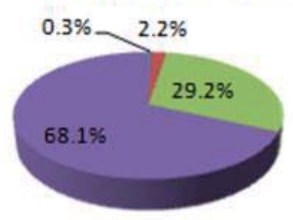

" Best
= Better
= Good
= poor 

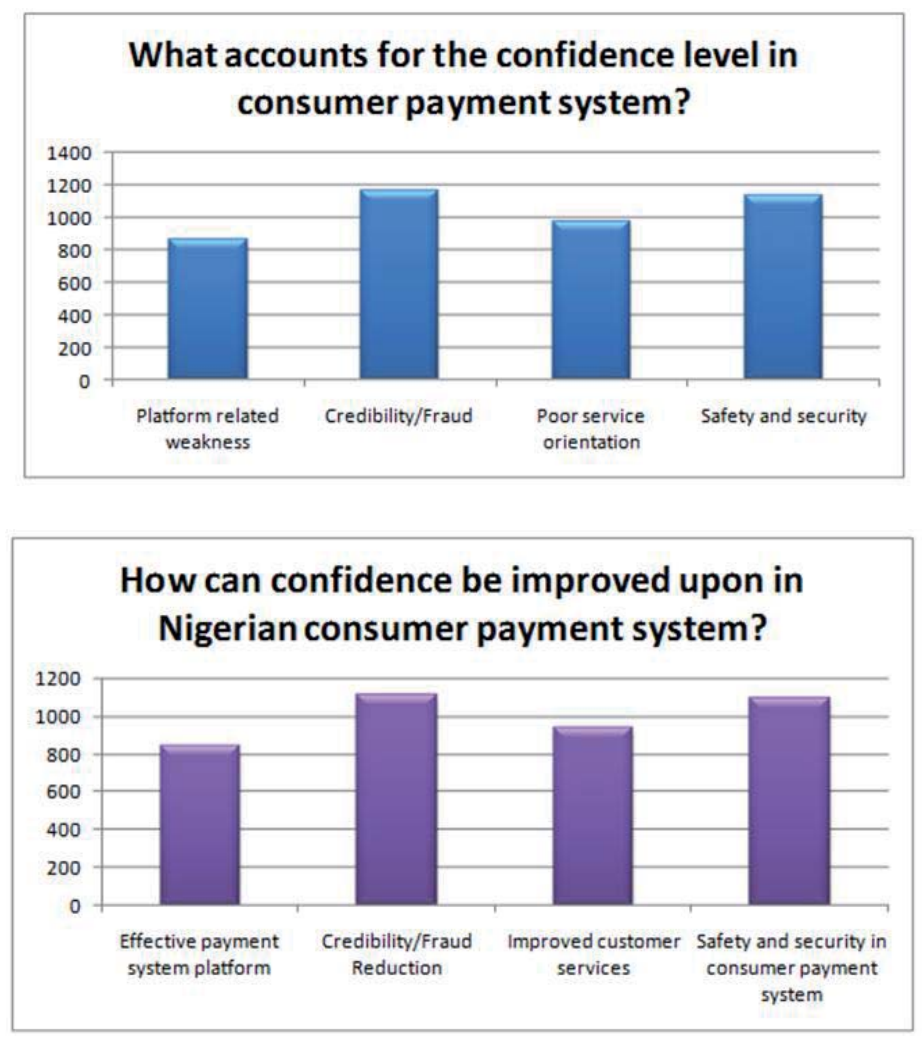

\section{References}

Adeoti O. \& Oshotomehin. (2011) Factors Influencing Adoption of Point of Sales Terminals in Nigeria. Journal of Emerging Trends in Economic and Managements Sciences (JETEMS) Vol 2 NO 5 388-392.

Adeyemo. K.A.(2012) Frauds in Nigerian Banks:Nature Deep-Seeted Causes, Aftermaths and Probable Remedies, Mediterranean Journal Global Sciences, Vol 3, NO 2, 279-289

Agene, C.E (1999). The Nigeria Payment System Evolutions, Problem and prospects .Journal of Chartered Institute Bankers April-June, pp16-19

Alan L. Tyree (2012) Regulating the Payment System. Part 2 (Consumer protection. See http;//www.austihi.edu.au u alan/payment-re$2 /$ htrms assessed $15^{\text {th }}$ of june.

Asolo Adeyeye. A.A (2001) New Global business moral order and Business Activities in developing countries: The Nigerian Experience in John Cooker (eds.) Perspectives on International Corporate Responsibility, International Management Series Vol. 4 Pittsburgh, Carnegie Mellon University pp 286-302.

Asolo Adeyeye .A. 2001. Maximizing the Gains of privatization Towards Economic Growth in Nigeria. African Journal of Business and Economic Research Vol. 2. No1. 263-267.

Ayo. C.K and Babajide. D.O (2006) Designing a reliable payment system: Nigeria as a case study. Journal of Internet Banking and Commerce, Vol 11 N0 2. http//www.arrayder.com/commerce/jibc.

Bruce.J. Summers (ed) 2012, Paymen System: Design, Governance and Oversight, Central Banking Publication, pp3

Central Bank of Nigeria (CBN) (2014) http//www.cen.org retrieved 15th April,

Central Bank of Nigeria (CBN) Policy circular Ref No. FPR/DIR/CIR/GEN/03/005,July $5^{\text {th }}, 2013$.

Central Bank of Nigeria (2013) Payment System Vision 2020. Release 2.0 September, http:www.cbn.gov.ng/icps2013/papers/ NigeriaPaymentSystemVision2020 Pdf. Assessed 16 ${ }^{\text {th }}$ November 2013

CPSS, 2001 Core Principle for Systematic Based Improved Payment System, Switzerland Bank for International Settlement Information, Press and Library Services January.

Electronic fund Transfer: Report of the Treasury and Australian competition and consumer commission on the operation of the EFI code of conduct march, 1998.

Elfriede.Penze \&Rudolf. R.Sinkovics, (2013) Triangulating Consumer Perceptions of Payments System by Using Social Representation Theory: A Multi-Method Approach, Journal of Consumer Behaviour Vol 12, issue 4,pg 293-306

Financial system research council. The Working Group Reports On Electronic Payment System. May 2, 1977. http://www.fsa.gp.5p/ pmof/English/e/a/1201.html 16/01/05

Federal Reserve Bank 2013. Payment System Improvement: Public Consultation paper, September 10, 2012 
kpefan. O.A. 2007 (Impact of Bank Capitalization in the Performance of Nigerian Banking Industry (1986-2006). The Journal of commerce, Vol 4, No 1,

Magnuson, W.G \& Carper.J. (1968) The Dark Side of the Market Place, the Plight of the American consumer. New Jersey Eaglewood cliffs, Prentice Hall.

Mark. E. Budnitz (2008) Technology as the driver of payment system rules: Will consumer be provided seatbelt an airbags, ChicagoKent Law Review, Article 16, Issue 2, Vol 83, pp 909-936

Menon. B. \& Jagathy. R.V.P (2012) Model Development and Validation for Preferences of car owners. International Journal of Marketing and Technology (IJMT) Vol 2, Issue No 5 pp 149-1

Ogumma P.A (1996) Problems and Challenge of Developing an Efficient Payment System in Nigeria. The Nigerian Banker JulyDecember pp7-9.

Owolabi. E.A (2007) Corruption and Financial crimes in Nigeria: Genesis, Trends and consequences. http//www.centbank.org/out/ Publications/Transparency/2007, assessed July 142013

CIBN 2004 Recent Innovations in the Nigerian payment system The Nigeria Banker, Journal of the Chartered Institute of Bankers of Nigeria (CIBN) April-June P 2329.

Sanni .A. Abdulahi 2009 Assessment of the impacts of banking sector consolidation on the real sector of the Nigeria economy, Journal of finance and accounting research Vol 1, No 3, September.

Shokan.O.O. (1999) Research Seminar and methodology for all Disciplines, Lagos. Shona Investment Limted PP 84 - 90.

Singh. Summanjeer (2009) Emergence of Payment Systems in the Age of Electronic Commerce: The State of Art. Asia Pacific Journal of Finance and Banking Vol 3, No 3, pp 18-40. 